\title{
Application of Nanotechnology in Photovoltaic
}

\section{Yan $\mathrm{F}^{*}$}

College of Nanoscale Science and Engineering, State University of New York, USA

${ }^{*}$ Corresponding author: Yan F, US Photovoltaic Manufacturing Consortium, College of Nanoscale Science and Engineering, State University of New York, Albany, NY 12203, USA

Citation: Yan F (2013) Application of Nanotechnology in Photovoltaic. J Mater Sci Nanotechnol 1(2): e201. doi: 10.15744/2348-9812.1.e201

\section{Received Date: October 23, 2013 Accepted Date: October 25, 2013 Published Date: October 28, 2013}

Nanotechnology mainly consists of the processing, separation, consolidation, and deformation of materials by one atom or by one molecule [1]. It is an applied research of materials and devices operated at nanometer scale. The nanostructures can significantly change material properties such as special conductivity, specific heat, and quantum confinement effects. The application of nanotechnology can reduce materials consumed in manufacturing processes and energy consuming during operation. Till now, nanotechnology has being applied to various fields related to energy, among them energy storage, conversion, manufacturing improvements by reducing materials, energy saving, and renewable energy devices [2-8].

Energy is strongly demanded due to a shortage of fossil fuel supplies and record-high oil prices. The concern over the environment would be markedly narrowed with a cleaner and renewable energy source [9]. Giving everyone access to affordable, clean and secure energy is primary to making progress on many other human challenges in the future. Among the potential renewable energy sources, solar energy, especially the photovoltaic (PV) technology which directly transfers sunlight to electricity, is extremely promising. PV panels not only can be plugged into existing grid infrastructure once converted to AC, they also can be used for off-grid applications like portable charger and space applications. By combining with energy storage techniques, PV panels can be considered a major energy source in remote housing. With the support of government funding and venture capital investors, PV manufacturing and installations keep growing even with the challenging fiscal conditions over the last two years. IHS forecasted 35 GW PV panels would be installed in 2013, up 10 percent over 2012 [10].

To achieve higher efficiency solar cells, material science and nanotechnology are also widely working in thin film photovoltaic devices [11,12]. Comparing to conventional silicon PV panels, thin film solar panels have advantages in low-light applications, flexibility, low weight and roll-to-roll production capability. Another advantage is that they exhibit a higher watt-peak capability for their given power rating based on a net power per day [13]. Through applications of material sciences and nanotechnology, single junction thin film solar cells have achieved efficiencies of $20.4 \%$ in CIGS solar cell, $19.6 \%$ in CdTe solar cell, $11.9 \%$ in dye sensitized solar cell, 9.2\% in organic solar cell, and $8.5 \%$ in CZTS solar cell [14]. CdTe and CIGS PV are the most successful type of commercially available thin-film PV panels with 12.9-15.7\% module efficiency, while other thin film solar cells are still in the pre-commercial phase.

My research in material science and nanotechnology has covered several types of thin film solar cells, from developing CIGS solar cell interconnection methods [15] to demonstration of semitransparent organic solar modules passing accelerated chamber tests [16], and application of nanostructures in dye sensitized solar cells [11]. It is essential that intensive research efforts should be continued to bring the manufacturing cost of solar panels to an affordable level for large scale production of electricity. Recent research carried at US Photovoltaic Manufacturing Consortium (PVMC) aims to increase performance and speed the implementation of PV technologies while reducing the cost of PV systems by about 75 percent over the next decade. The US PVMC is a PV supply chain partnership under the DOE Sun Shot Initiative. PVMC has achieved CIGS solar cell efficiency over 18\%. The focus of the consortium is to address challenges relating to the manufacturing of PV based devices through a public-private partnership using both lab scale and MW scale production capabilities setup at PVMC for use by its partner companies.

I am proud to serve as an Editorial Board member of Journal of Materials Science and Nanotechnology. As an Editorial Board member, welcome all contributors to Journal of Materials Science and Nanotechnology!

\section{References}

1. Taniguchi N (1974) On the basic concept of 'nano-technology'. Proc Intl Conf Prod Eng Tokyo, Part II, Japan Society of Precision Engineering 5-10.10. 2. Park SJ, Taton TA, Mirkin CA (2002) Array-based electrical detection of DNA with nanoparticle probes. Science 295: 1503-6.

3. Tian Y, Shao G, Wang X, Linan A (2013) Fabrication of nano-scaled polymer-derived SiAlCN ceramic components using focused ion beam. J Micromech Microeng 23: 9.

4. Huo HB, Wang C, Yan FD, Ren HZ, Shen MY (2009) Room temperature $\mathrm{SnO} 2$ thin film gas sensor fabricated on Si nanospikes. J Nanosci Nanotechnol 9: 4817-9.

5. Baughman RH, Zakhidov AA, de Heer WA (2002) Carbon nanotubes--the route toward applications. Science 297: 787-92. 
6. Tian Y,Wu N, Zou X, Felemban H, Cao C, et al. (2013) Fiber-optic ultrasound generator using periodic gold nanopores fabricated by a focused ion beam. Optical Engineering 52: 065005

7. Huh P, Yan F, Li L, Kim M, Mosurkal R, et al.(2008) Simple fabrication of zinc oxide nanostructures. J Mater Chem 18: 637-9.

8. Tian Y, Wu N, Sun K, Zou X, Wang X (2013) Numerical simulation of fiberoptic photoacoustic generator using nanocomposite material. J Comp Acous 21: 1350002 .

9. Keeling CD, Whorf TP, Wahlen M, Plichtt JV (1995) Interannual extremes in the rate of rise of atmospheric carbon dioxide since 1980. Nature 375: 666-70.

10. Photovoltaic Module Shipments Surge in the Fourth Quarter of 2012, Accessed Jan 2013 (Press Releases).

11. Yan F, Huh P, Li L, Wang Y, Samuelson LA, et al. (2009) Photovoltaic performance enhancement in dye-sensitized solar cells with periodic surface relief structures. J M S Pure appl chem: 1213-16.
12. Green MA (2002) Lambertian light trapping in textured solar cells and light-emitting diodes: analytical solutions. Prog Photovolt: Res Appl 10: 23541.

13. Gottschalg R, Infield DG, Kearney MJ (2003) Experimental study of variations of the solar spectrum of relevance to thin film solar cells. Solar Energy Materials \& Solar Cells 79: 527-37.

14. Green MA, Emery K, Hishikawa Y, Warta W, Dunlop ED (2013) Solar cell efficiency tables (version 42). Progress in Photovoltaics: Research and Applications 21: 827-37.

15. Yan F, Metacarpa DJ, Sundaramoorthy R, Fobare D, Haldar P (2013) Evaluation of CIGS Cell Interconnection Methods. Photovoltaic Specialists Conference (PVSC), 39th IEEE Tampa, Florida.

16. Yan F, Noble J, Peltola J, Wicks S, Balasubramanian S (2013) Semitransparent OPV modules pass environmental chamber test requirements. Solar Energy Materials \& Solar Cells 114: 214-18. 